\title{
Optimization Design of the Multi-stage Inventory Management for Supply Chain
}

\author{
Hongxing Deng*, Ting Yuan and Chunli Yan \\ Transportation College, Northeast Forestry University, Harbin 150040, P. R. \\ China \\ E-mail:1969dhx@163.com
}

\begin{abstract}
Aiming at the problem of multi echelon inventory management logistics network based on the concept, the automobile spare parts warehousing logistics as the breakthrough point, the supply chain inventory total profit as the objective function, the automobile spare parts supply chain inventory model is optimized, the multi echelon inventory management strategy, the strategy makes the enterprise inventory cost is reduced, the production efficiency is increased.
\end{abstract}

Keywords: supply chain, inventory management, hierarchical design optimization, management strategy

\section{Introduction}

The current globalization of economy and internationalization of market make the competitions among production enterprises turn to the supply chain [1]. Supply chain refers to the logistics network system from the purchase of raw materials to sales of the final product, contacting with suppliers, manufacturers, distributors, retailers and other related industries, containing the processes of processing, assembly, distribution of products, etc. In the whole link, process, processing, sales, each enterprise chain needs sufficient inventory to maintain the enterprise's production and operating activities within supply, and the inventory's operation and management will increase the production cost of enterprises [2, 3]. Therefore, to determine the optimal ordering strategy and reduce the supply chain inventory and achieve the purpose of maximizing profits is an important part of enterprise management decisions, helpful to the enterprise's market competitiveness.

At present, supply chain management has become the key research content at home and abroad [4-7]. Especially the progress and development of China's automobile industry provide the material guarantee for the research of supply chain. In 2014, total market demand will be more than 20 million cars in our country. Faced with such a huge automobile market, it will necessarily bring a huge auto spare parts market. According to statistics, auto market value after sale in China in 2011 is about 400 billion RMB, and will reach 700 billion RMB expected in 2015 . Obviously the automobile spare parts inventory in the supply chain plays a very important role. Automobile after-sale spare parts supply chain, from suppliers, manufacturers, distributors to retailers, each link has inventory, thus a chain of inventory is formed, inventory chain of each node in the inventory not only affects the cost of a node enterprises, but also restricts between upstream and downstream enterprises, and even the comprehensive cost, the overall performance and competitive advantage of the entire supply chain. In each circulation, setting auto spare parts inventory can satisfy the uncertainty of customer demands [8]. The link in the supply chain inventory management involves multiple products and the rate 
of order [9], in addition, also involves the relationship between the upstream and downstream enterprises, namely the multistage stock management [10].

If the control of the spare parts inventory is not reasonable, which will result in a great increase in the automobile spare parts supply chain inventory and make the whole supply chain total inventory cost increase by $20 \% \sim 40 \%$. This paper is for supply chain inventory problem then systematically to analyze and design, expecting to get the best inventory optimization, reduce the inventory cost, improve market competitiveness.

\section{Auto Spare Parts Logistics Mode and the Analysis of Inventory Management}

The automobile supply chain system is mainly composed of raw materials, spare parts supply chain, the whole car manufacturers, distributors, service station, the third party logistics enterprise and automobile users [11]. Spare parts logistics as the body of the after-sales service market, with the decline of profit in new car sales and gradually become an important source of corporate profits [12]. With the continuous development and improvement of auto spare parts market, the constitution of automobile spare parts supply chain presents the trend of network and complication [13]. For now, automobile spare parts supply chain can be divided into three components, auto spare parts manufacturing enterprise, automobile spare parts distribution enterprise, spare parts service station.

Our country's automobile spare parts logistics mode mainly includes the following:

First, the vehicle manufacturing enterprises provide the products to customers through the repair station and 4S shops [14].

Second, the vehicle manufacturing enterprises provide parts of the product to the customer, the other parts to small repairing and spare parts dealers through the automobile trade company.

Third, manufacturing enterprises provide the products to regional distributors, the latter distributes them to the downstream distributors and customers.

Fourth, spare parts manufacturing enterprises have their self-management model, some parts manufacturers are also directly involved in auto spare parts market, and set up their own logistics system to run.

Considering the reasons, auto spare parts logistics multistage stock inventory of our country can be classified according to the specific way of logistics in China.

\subsection{Problems Existing in the Spare Parts Inventory}

According to the survey: A Harbin automobile spare parts wholesaler owning more than 6000 different kinds of spare parts inventory is named as $A$ company, who purchases directly from components manufacturing company in Hangzhou, and then distributed to various spare parts dealers. As a result of so many types of auto spare parts, such as the uncertainty of customer demand, customer demand for service quality, bringing much difficulty in automotive spare parts inventory management.

The existing problems by investigating are as follows:

The capital and safety stock of spare parts take an important role, $A$ company usually make a purchase from the supplier in 15 days, and automobile spare parts procurement will be served in 8 days, but the safety stock can be stored for a month, which takes up a lot of inventory cost and a large number of depreciation cost virtually.

The occupancy rate for the warehouse is high, A company warehouse occupancy rate is as high as $80 \%$, while maintaining high stock levels can reduce the loss caused by out of stock, also brings a bit of difficulty in the inventory check and count, which is not conducive to the management. 
Obviously the classification management of $A$ company is not reasonable and scientific for its automobile spare parts. For example: $A$ spare parts company, in the spare parts purchasing and storage is determined by the market experience with its all kinds of spare parts purchasing in bulk, although it is based on the practical experience as a very good reference value, but not a system of classified management methods to help improve the management benefit of the enterprise and reduce the inventory cost. What's more, $A$ company supply chain has the lack of co-ordination in spare parts inventory. For example: A company simply pays attention to the benefit between company and its customers, therefore information with each other is not transparent in many aspects, which causes great influence in projection and judgment for $A$ company, who can only rely on its experience to predict customer demand, thus increasing its inventory.

\subsection{Auto Spare Parts Company ABC Inventory Classification Management}

$\mathrm{ABC}$ classification, also called primary and secondary factors analysis, is according to the aspect in the main characteristics of the economic or technology to classify queue, distinguish the key and general, and make a difference in the management way of a analysis method [15].

Making an implementation of $\mathrm{ABC}$ taxonomy according to $A$ company's inventory management problem, on the bases of reasonable classification, working out a corresponding inventory control strategy according to different automobile spare parts. There was a classification research drawn from $A$ company's dozens of spare parts in its warehouse and got some spare parts sales within a month based on a field survey of $A$ company, the specific data are shown in Table 1.

Table 1. Parts of the Spare Parts Sales of A Company

\begin{tabular}{|c|c|c|c|c|c|}
\hline NO. & NAME & unit & Unit price(yuan) & Quantity & time \\
\hline 1 & ignition coil & PCS & 428 & 760 & 1month \\
\hline 2 & S-M oil & barrel & 285 & 660 & 1month \\
\hline 3 & $\begin{array}{l}\text { Air filter element- } \\
\text { B12 }\end{array}$ & PCS & 59 & 2200 & 1 month \\
\hline 4 & Timing belt & PCS & 243 & 442 & 1month \\
\hline 5 & $\begin{array}{c}\text { Gasoline filter } \\
\text { element }\end{array}$ & PCS & 72 & 1150 & 1month \\
\hline 6 & Rivet & PCS & 15 & 4678 & 1 month \\
\hline 7 & $\begin{array}{l}\text { Former brake } \\
\text { block }\end{array}$ & PCS & 316 & 175 & 1month \\
\hline 8 & Tire & PCS & 520 & 58 & 1month \\
\hline 9 & Starter & PCS & 900 & 32 & 1month \\
\hline 10 & generator & PCS & 800 & 33 & 1month \\
\hline 11 & tooth-shaped belt & PCS & 145 & 167 & 1month \\
\hline 12 & Astern mirror & PCS & 140 & 150 & 1month \\
\hline 13 & Gear oil & barrel & 129 & 160 & 1month \\
\hline 14 & High braking lamp & PCS & 115 & 150 & 1month \\
\hline 15 & Tail light & PCS & 110 & 140 & 1month \\
\hline 16 & antifreeze & barrel & 85 & 212 & 1month \\
\hline 17 & Brake pedal & PCS & 76 & 220 & 1month \\
\hline 18 & Brake disc & PCS & 410 & 24 & 1month \\
\hline 19 & Fuel tub & PCS & 180 & 48 & 1month \\
\hline 20 & Back oil seal of & PCS & 89 & 98 & 1month \\
\hline 21 & Rear shock Absorb & PCS & 150 & 50 & 1month \\
\hline 22 & $\begin{array}{c}\text { Fore-balance ball } \\
\text { head }\end{array}$ & PCS & 65 & 80 & 1 month \\
\hline 23 & steering linkage & PCS & 160 & 32 & 1month \\
\hline 24 & Combination & PCS & 135 & 30 & 1 month \\
\hline
\end{tabular}




\begin{tabular}{|c|c|c|c|c|c|}
\hline 25 & $\begin{array}{c}\text { switch } \\
\text { thermostat }\end{array}$ & PCS & 30 & 120 & 1month \\
\hline 26 & $\begin{array}{c}\text { Water temperature } \\
\text { plug }\end{array}$ & PCS & 35 & 90 & 1 month \\
\hline $\begin{array}{l}27 \\
28 \\
29\end{array}$ & $\begin{array}{l}\text { Front hub } \\
\text { fuse } \\
\text { Mud skin }\end{array}$ & $\begin{array}{l}\text { PCS } \\
\text { PCS } \\
\text { PCS }\end{array}$ & $\begin{array}{c}100 \\
2 \\
50\end{array}$ & $\begin{array}{c}30 \\
1408 \\
50\end{array}$ & $\begin{array}{l}1 \text { month } \\
1 \text { month } \\
1 \text { month }\end{array}$ \\
\hline 30 & $\begin{array}{l}\text { Back braking pad- } \\
\text { B12 }\end{array}$ & PCS & 70 & 35 & 1 month \\
\hline 31 & $\begin{array}{l}\text { Front braking pad- } \\
\text { B12 }\end{array}$ & PCS & 55 & 40 & 1 month \\
\hline $\begin{array}{l}32 \\
33\end{array}$ & $\begin{array}{l}\text { Spark plug-B12 } \\
\text { Tyre nut-B12 }\end{array}$ & $\begin{array}{l}\text { PCS } \\
\text { PCS }\end{array}$ & $\begin{array}{c}25 \\
8\end{array}$ & $\begin{array}{c}80 \\
220\end{array}$ & $\begin{array}{l}1 \text { month } \\
1 \text { month }\end{array}$ \\
\hline 34 & License plate & PCS & 30 & 58 & 1 month \\
\hline 35 & Horn & PCS & 40 & 30 & 1month \\
\hline 36 & Input axis oil seal & PCS & 22 & 50 & 1 month \\
\hline 37 & $\begin{array}{l}\text { Front fog-light } \\
\text { switch }\end{array}$ & PCS & 36 & 25 & 1 month \\
\hline 38 & Front brake hose & PCS & 16 & 50 & 1 month \\
\hline 39 & $\begin{array}{c}\text { Dynamic steering } \\
\text { belt }\end{array}$ & PCS & 25 & 20 & 1month \\
\hline 40 & Fuel cap & PCS & 15 & 15 & 1 month \\
\hline
\end{tabular}

To take the ABC classification extraction in 40 kinds spare parts from A company's spare parts list, these spare parts sell for 1256474 RMB in a month, to classify each spare parts month sales as a standard, spare parts sales accounted for $75 \%$ of the total amount is divided into class $A, 20 \%$ of the total is divided into class $B, 5 \%$ of the total is divided into class $C$. After ABC classification division, there are 6 kinds of class $A$ spare parts, 12 kinds of class $B$ spare parts, 22 kinds of class $C$ spare parts in the 40 kinds of spare parts. The spare parts classification situations are shown in Table 2.

Table 2. ABC Classification in the Spare Parts of $A$ Company

\begin{tabular}{|c|c|c|c|c|c|c|c|}
\hline no. & name & $\begin{array}{l}\text { Unit } \\
\text { price }\end{array}$ & quantity & sales & $\begin{array}{l}\text { Sales } \\
\text { totally }\end{array}$ & $\begin{array}{l}\text { Cumulative } \\
\text { percentage } \\
\text { of sales }\end{array}$ & $\begin{array}{c}\text { The } \\
\text { classification } \\
\text { results }\end{array}$ \\
\hline 1 & ignition coil & 428 & 760 & 325280 & 325280 & $25.9 \%$ & $A$ \\
\hline 2 & S-M oil & 285 & 660 & 188100 & 513380 & $40.9 \%$ & A \\
\hline 3 & $\begin{array}{c}\text { Air filter } \\
\text { element-B12 }\end{array}$ & 59 & 2200 & 129800 & 643180 & $51.2 \%$ & A \\
\hline 4 & Timing belt & 243 & 442 & 107406 & 750586 & $59.7 \%$ & A \\
\hline 5 & $\begin{array}{l}\text { Gasoline filter } \\
\text { element }\end{array}$ & 72 & 1150 & 82800 & 833386 & $66.3 \%$ & A \\
\hline 6 & Rivet & 15 & 4678 & 70170 & 903556 & $71.9 \%$ & A \\
\hline 7 & $\begin{array}{l}\text { Former brake } \\
\text { block }\end{array}$ & 316 & 175 & 55300 & 958856 & $76.3 \%$ & B \\
\hline 8 & Tire & 520 & 58 & 30160 & 989016 & $78.7 \%$ & B \\
\hline 9 & Starter & 900 & 32 & 28800 & 1017816 & $81.0 \%$ & B \\
\hline 10 & generator & 800 & 33 & 26400 & 1044216 & $83.1 \%$ & B \\
\hline 11 & $\begin{array}{c}\text { tooth-shaped } \\
\text { belt }\end{array}$ & 145 & 167 & 24215 & 1068431 & $85.0 \%$ & B \\
\hline $\begin{array}{l}12 \\
13\end{array}$ & $\begin{array}{l}\text { Astern mirror } \\
\text { Gear oil }\end{array}$ & $\begin{array}{l}140 \\
129\end{array}$ & $\begin{array}{l}150 \\
160\end{array}$ & $\begin{array}{l}21000 \\
20640\end{array}$ & $\begin{array}{l}1089431 \\
1110071\end{array}$ & $\begin{array}{l}86.7 \% \\
88.3 \%\end{array}$ & $\begin{array}{l}\mathrm{B} \\
\mathrm{B}\end{array}$ \\
\hline 14 & $\begin{array}{l}\text { High braking } \\
\text { lamp }\end{array}$ & 115 & 150 & 17250 & 1127321 & $89.7 \%$ & B \\
\hline $\begin{array}{l}15 \\
16\end{array}$ & $\begin{array}{l}\text { Tail light } \\
\text { antifreeze }\end{array}$ & $\begin{array}{c}110 \\
85 \\
76\end{array}$ & $\begin{array}{l}140 \\
212 \\
220\end{array}$ & $\begin{array}{l}15400 \\
18020 \\
16720\end{array}$ & $\begin{array}{l}1142721 \\
1160741 \\
1177461\end{array}$ & $\begin{array}{l}90.9 \% \\
92.4 \% \\
93.7 \%\end{array}$ & $\begin{array}{l}B \\
B \\
R\end{array}$ \\
\hline 17 & Brake pedal & 76 & 220 & 16720 & 1177461 & $93.7 \%$ & B \\
\hline
\end{tabular}




\begin{tabular}{|c|c|c|c|c|c|c|c|}
\hline $\begin{array}{l}18 \\
19\end{array}$ & $\begin{array}{c}\text { Brake disc } \\
\text { Fuel tub }\end{array}$ & $\begin{array}{l}410 \\
180\end{array}$ & $\begin{array}{l}24 \\
48\end{array}$ & $\begin{array}{l}9840 \\
8640\end{array}$ & $\begin{array}{l}1187301 \\
1195941\end{array}$ & $\begin{array}{l}94.5 \% \\
95.2 \%\end{array}$ & $\begin{array}{l}\mathrm{B} \\
\mathrm{C}\end{array}$ \\
\hline 20 & $\begin{array}{l}\text { Back oil seal } \\
\text { of Crankshaft }\end{array}$ & 89 & 98 & 8722 & 1204663 & $95.9 \%$ & C \\
\hline 21 & $\begin{array}{l}\text { Rear shock } \\
\text { Absorb }\end{array}$ & 150 & 50 & 7500 & 1212163 & $96.5 \%$ & $\mathrm{C}$ \\
\hline 22 & $\begin{array}{c}\text { Fore-balance } \\
\text { ball head }\end{array}$ & 65 & 80 & 5200 & 1217363 & $96.9 \%$ & C \\
\hline 23 & $\begin{array}{l}\text { steering } \\
\text { linkage }\end{array}$ & 160 & 32 & 5120 & 1222483 & $97.3 \%$ & C \\
\hline 24 & $\begin{array}{l}\text { Combination } \\
\text { switch }\end{array}$ & 135 & 30 & 4050 & 1226533 & $97.6 \%$ & C \\
\hline 25 & $\begin{array}{l}\text { thermostat } \\
\text { Water }\end{array}$ & 30 & 120 & 3600 & 1230133 & $97.9 \%$ & C \\
\hline 26 & $\begin{array}{l}\text { temperature } \\
\text { plug }\end{array}$ & 35 & 90 & 3150 & 1233283 & $98.2 \%$ & C \\
\hline 27 & Front hub & 100 & 30 & 3000 & 1236283 & $98.4 \%$ & C \\
\hline 28 & fuse & 2 & 1408 & 2816 & 1239099 & $98.6 \%$ & C \\
\hline 29 & Mud skin & 50 & 50 & 2500 & 1241599 & $98.8 \%$ & $\mathrm{C}$ \\
\hline 30 & $\begin{array}{l}\text { Back braking } \\
\text { pad-B12 }\end{array}$ & 70 & 35 & 2450 & 1244049 & $99.0 \%$ & C \\
\hline 31 & $\begin{array}{l}\text { Front braking } \\
\text { pad-B12 }\end{array}$ & 55 & 40 & 2200 & 1246249 & $99.2 \%$ & C \\
\hline 32 & $\begin{array}{c}\text { Spark plug- } \\
\text { B12 }\end{array}$ & 25 & 80 & 2000 & 1248249 & $99.3 \%$ & $\mathrm{C}$ \\
\hline 33 & Tyre nut-B12 & 8 & 220 & 1760 & 1250009 & $99.5 \%$ & C \\
\hline 34 & License plate & 30 & 58 & 1740 & 1251749 & $99.6 \%$ & C \\
\hline 35 & Horn & 40 & 30 & 1200 & 1252949 & $99.7 \%$ & C \\
\hline 36 & $\begin{array}{c}\text { Input axis oil } \\
\text { seal }\end{array}$ & 22 & 50 & 1100 & 1254049 & $99.8 \%$ & C \\
\hline 37 & $\begin{array}{l}\text { Front fog-light } \\
\text { switch }\end{array}$ & 36 & 25 & 900 & 1254949 & $99.9 \%$ & $\mathrm{C}$ \\
\hline 38 & $\begin{array}{c}\text { Front brake } \\
\text { hose }\end{array}$ & 16 & 50 & 800 & 1255749 & $99.9 \%$ & C \\
\hline 39 & $\begin{array}{c}\text { Dynamic } \\
\text { steering belt }\end{array}$ & 25 & 20 & 500 & 1256249 & $100.0 \%$ & C \\
\hline 40 & Fuel cap & 15 & 15 & 225 & 1256474 & $100.0 \%$ & C \\
\hline
\end{tabular}

After the classification of spare parts, $A$ company can take different inventory control strategies, in order to save inventory costs, reduce inventory and improve the market competitiveness in the situation of meeting demand of the customers. According to different categories of spare parts, inventory control strategies taken are shown in Table 3.

Table 3. Three Types of Inventory Control Strategy and Method

\begin{tabular}{cccc}
\hline Project/level & A class of inventory & $\begin{array}{c}\text { B class of } \\
\text { inventory }\end{array}$ & $\begin{array}{c}\text { C class of } \\
\text { inventory }\end{array}$ \\
\hline The degree of control & Strict & General & Simple \\
Inventory calculation & $\begin{array}{c}\text { Calculation in detail based on } \\
\text { the inventory model }\end{array}$ & $\begin{array}{c}\text { General } \\
\text { Record }\end{array}$ & Simple \\
The record of In- out & Record in detail & $\begin{array}{c}\text { Renerally } \\
\text { gecord simply }\end{array}$ & \\
Inventory check & Intensive & General & Lower \\
frequency & General & Bigger & Bigger \\
Safety stock & & &
\end{tabular}




\section{Automobile Spare Parts Multilevel Inventory System Model Analysis}

Obviously, involving A company spare parts inventory chain system including components manufacturing enterprises, automobile spare parts wholesale, auto spare parts dealers three levels, automobile spare parts wholesaler and auto spare parts dealers order lead time and customer demand is auto spare parts dealers are random variables. Through the system constraints determine (order quantity of inventory system at all levels, the maximum inventory, order quantity, etc.), Building mathematical model of multi-level inventory systems and multistage inventory system for system simulation, obtain the optimal solution of multi-stage inventory system model through optimization algorithm.

In determining the auto spare parts dealers, auto spare parts wholesaler inventory node ordering strategy, including at all levels the inventory cycle inventory node, reorder point and order quantity and other constraints, to solve the multi-stage inventory system optimization goal. The multi-stage supply chain inventory optimization can be divided into cost optimization and time optimization, etc., base on the total supply chain profit maximum as auto spare parts multistage inventory optimization goal.

(1)Inventory maintenance cost of automobile spare parts wholesaler

As long as the car spare parts wholesaler $j$ has products, namely $U_{j}(t) \geqslant 0$, inventory maintenance cost will be produced. The inventory maintenance cost of auto parts wholesaler $j$ in the planning period is denoted as:

$$
H_{j}=\mathrm{h}_{j} \cdot \int_{0}^{T} U_{j 1}(t) d_{t}=h_{j} \int_{0}^{T} \operatorname{Max}\left(U_{j}(t), 0\right) d_{t}
$$

(2) Shortage cost of automobile spare parts wholesaler

When the automobile spare parts wholesaler cannot meet the needs of downstream of auto spare parts dealers, namely $U_{j}(t) \geqslant 0$, generated shortage cost will be produced, so the shortage cost of the automotive spare parts wholesaler $\mathrm{j}$ in the planning period is denoted as:

$$
B_{j}=b_{j} \cdot \int_{0}^{T} U_{j 2}(t) d_{t}=b_{j} \int_{0}^{T} \operatorname{Max}\left(-U_{j}(t), 0\right) d_{t}
$$

(3) The ordering cost of automobile spare parts wholesaler

Each time the automobile spare parts wholesaler $j$ places an order with upstream manufacturers of auto parts, the corresponding ordering cost will be produced, ordering cost constituted by two elements, including fixed ordering cost $G_{l j}$ and variable ordering cost $G_{2 j}$, so the total ordering costs of the automotive spare parts wholesaler $j$ in the planning period is denoted as:

$$
D_{j}=k_{j} \cdot\left(G_{1 j}+G_{2 j} \cdot R_{j}\right)
$$

Inventory costs, holding cost, ordering cost and shortage cost of automobile spare parts dealers $i$ and automobile spare parts wholesaler $j$ have the same composition. $U_{i}(t)$ is the theoretical inventory of automobile spare parts dealer $i$ for the moment $t$, decrease with the downstream customer orders. When The automobile spare parts dealer $i$ places an order with its upstream automobile pares parts wholesaler, when the inventory level drops to the reorder point $R_{i}$. For $U_{i l}(t)$ is the actual inventory of auto spare parts dealers for time $t, U_{i l}(t)=\operatorname{Max}\left(U_{i}(t), 0\right) ; U_{i 2}(t)$ is the actual inventory of auto spare parts dealers for time $t, U_{i 2}(t)=\operatorname{Max}\left(-U_{i}(t), O\right)$; Automobile spare parts dealer $i$ also take $\left(T_{i}, R_{i}, Q_{i}\right)$ inventory control strategy, namely $\left(T_{i}, R_{i}, Q_{i}\right)$ strategy. Similar with the automobile spare parts wholesaler, inventory cost of automobile spare parts dealer are as follows:

(1) Inventory maintenance cost of automobile spare parts dealers $i$ as follows:

$$
H_{\mathrm{i}}=\mathrm{h}_{i} \cdot \int_{0}^{T} U_{i 1}(t) d_{t}=h_{i} \int_{0}^{T} \operatorname{Max}\left(U_{i}(t), 0\right) d_{t}
$$

(2)The shortage cost of auto spare parts dealers $i$ is: 


$$
B_{\mathrm{i}}=b_{i} \cdot \int_{0}^{T} U_{i 2}(t) d_{t}=b_{i} \int_{0}^{T} \operatorname{Max}\left(-U_{i}(t), 0\right) d_{t}
$$

(3)The total ordering cost of auto spare parts dealers $i$ is:

$$
D_{\mathrm{i}}=k_{i} \cdot\left(G_{1 i}+G_{2 i} \cdot R_{i}\right)
$$

\subsection{Total Cost of Automobile Spare Parts Multilevel Inventory System}

The total net margin within the planned period of automobile spare parts multilevel inventory system is total selling profit of supply chain deducting inventory costs of all levels of inventory node. Total selling profit of supply chain, total inventory maintenance cost, total shortage cost, total ordering cost, total net margin as follows:

(1)Total selling profit of supply chain

The total selling profit of automotive spare parts supply chain has related to unit profit of product and total sales of automotive spare parts dealers $i$, total selling profit is:

$$
S=\sum_{i=1}^{N} S_{i}=\sum_{i=1}^{N} \int_{0}^{T} c X(i) d_{t}
$$

(2)Total inventory maintenance cost of automotive spare parts multilevel inventory system can be deduced from equation (1) and (5), the total inventory maintenance cost of automotive spare parts multilevel inventory system is:

$$
\begin{aligned}
& H=\sum_{\mathrm{i}=1}^{N} H_{i}+\sum_{j=1}^{M} H_{j}=\sum_{i=1}^{N} h_{i} \cdot \int_{0}^{T} U_{i 1}(t) d_{t}+\sum_{j=1}^{M} h_{j} \cdot \int_{0}^{T} U_{j 1}(t) d_{t} \\
& =\sum_{i=1}^{N} h_{i} \cdot \int_{0}^{T} \operatorname{Max}\left(U_{i}(t), 0\right) d_{t}+\sum_{j=i}^{M} h_{j} \cdot \int_{0}^{T} \operatorname{Max}\left(U_{j}(t), 0\right) d_{t}
\end{aligned}
$$

(3)Total shortage cost of automotive spare parts multilevel inventory system can be deduced from equation (2) and (6), the total shortage cost of automotive spare parts multilevel inventory system is:

$$
\begin{aligned}
& B=\sum_{\mathrm{i}=1}^{N} B_{i}+\sum_{j=1}^{M} B_{j}=\sum_{i=1}^{N} \mathrm{~b}_{i} \cdot \int_{0}^{T} U_{i 2}(t) d_{t}+\sum_{j=1}^{M} b_{j} \cdot \int_{0}^{T} U_{j 2}(t) d_{t} \\
& =\sum_{i=1}^{N} b_{i} \cdot \int_{0}^{T} \operatorname{Max}\left(-U_{i}(t), 0\right) d_{t}+\sum_{j=i}^{M} b_{j} \cdot \int_{0}^{T} \operatorname{Max}\left(-U_{j}(t), 0\right) d_{t}
\end{aligned}
$$

(4) Total ordering cost of automotive spare parts multilevel inventory system can be deduced from equation (3) and (7), the total ordering cost of automotive spare parts multilevel inventory system is:

$$
D=\sum_{i=1}^{N} D_{i}+\sum_{j=1}^{M} D_{j}=\sum_{i=1}^{N} k_{i} \cdot\left(G_{1 i}+G_{2 i} \cdot R_{i}\right)+\sum_{j=1}^{M} k_{j} \cdot\left(G_{1 j}+G_{2 j} \cdot R_{j}\right)
$$

(5) Total net margin of automotive spare parts multilevel inventory system

The total net margin of automotive spare parts multilevel inventory system is total selling profit subtracting total inventory maintenance cost, total shortage cost and total ordering cost. Can be obtained by equation (7) - (10).Total net margin of automotive spare parts multilevel inventory system is: 


$$
\begin{aligned}
& Z=S-H-B-D \\
& =\sum_{i=1}^{N} S_{i}-\left(\sum_{i=1}^{N} H_{i}+\sum_{j=1}^{M} H_{j}\right)-\left(\sum_{i=1}^{N} B_{i}+\sum_{j=1}^{M} B_{j}\right)-\left(\sum_{i=1}^{N} D_{i}+\sum_{j=1}^{M} D_{j}\right) \\
& =\sum_{i=1}^{N} \int_{0}^{T} c \cdot X(i) d_{t}-\sum_{i=1}^{N} h_{i} \cdot \int_{0}^{T} \operatorname{Max}\left(U_{i}(t), 0\right) d_{t}-\sum_{j=1}^{M} h_{j} \cdot \int_{0}^{T} \operatorname{Max}\left(U_{j}(t), 0\right) d_{t}- \\
& b_{i} \cdot \int_{0}^{T} \operatorname{Max}\left(-U_{i}(t), 0\right) d_{t}-\sum_{0}^{M} b_{j} \cdot \int_{0}^{T} \operatorname{Max}\left(-U_{j}(t), 0\right) d_{t}-\sum_{i=1}^{N} k_{i} \cdot\left(G_{1 i}+G_{2 i} \cdot R_{i}\right) \\
& -\sum_{0}^{M} k_{j} \cdot\left(G_{1 j}+G_{2 j} \cdot R_{j}\right)
\end{aligned}
$$

There are global variables:

$T$ : Planning cycle, namely time overall length of system simulation run, $t$ is a certain time point within planning cycles, which $0 \leqslant t \leqslant T$;

$M$ : The number of automobile spare parts wholesaler, $j$ is node ID of automobile spare parts wholesaler, which $1 \leqslant j \leqslant M$;

$N$ : The number of automobile spare parts dealers, $i$ is node ID of automobile spare parts dealers, which $1 \leqslant i \leqslant N$;

$T$

$Z$ : The total profits which multilevel inventory system produced within planning cycle

$H$ : The total inventory maintenance cost of multilevel inventory system within planning cycle $T$;

$B$ : The total shortage cost which multilevel inventory system produced within planning cycle $T$;

$D$ : The ordering cost which multilevel inventory system produced within planning cycle $T$;

$c$ : Market profit of one-piece product, said the difference value between sale price of automobile spare parts dealer and purchase price of automobile spare parts wholesaler.

Variables of automobile spare parts wholesaler:

$U_{j}(t)$ : Theory inventory level of automobile spare parts wholesaler $j$;

$U_{j l}(t)$ : Physical inventory level of automobile spare parts wholesaler $j$, $U_{j 1}(t)=\operatorname{Max}\left(U_{j}(t), 0\right)$;

$U_{j 2}(t)$ : Shortage of inventory of automobile spare parts wholesaler $j ; U_{j 2}(t)=\operatorname{Max}(-$ $\left.U_{j}(t), 0\right)$

$h_{j}$ : Unit inventory maintenance cost of automobile spare parts wholesaler $j$;

$H_{j}$ : Total inventory maintenance cost within the planning cycle of automobile parts wholesaler $j$;

$b_{j}$ : Unit shortage cost of automobile parts wholesaler $j$;

$B_{j}$ : Total shortage costs within the planning cycle of automobile parts wholesaler $j$,

$k_{j}$ : The ordering time within the planning cycle of automobile spare parts wholesaler $j$ to the automobile parts manufacturing enterprise

$G_{1 j}$ : Fixed ordering cost of automobile parts wholesaler $j$;

$G_{2 j}$ : Variable ordering cost of automobile parts wholesaler $j$;

$D_{j}$ : Total cost of automobile spare parts wholesaler $j$ within the planning cycle to order goods from automobile parts manufacturing enterprise;

$R_{j}$ : Order batch of automobile parts wholesaler $j$ each time;

Variables of automobile spare parts dealer:

$U_{i}(t)$ : Theory inventory level of automobile spare parts dealer $i$

$U_{i 1}(t)$ : Physical inventory level of automobile spare parts dealer $i, U_{i 1}(t)=\operatorname{Max}\left(U_{i}(t), 0\right)$;

$U_{i 2}(t)$ : Shortage of inventory of automobile spare parts dealer $i ; U_{i 2}(t)=\operatorname{Max}\left(-U_{i}(t), 0\right)$,

$h_{i}$ : Unit inventory maintenance cost of automobile spare parts dealer $i$; 
$H_{i}$ : Total inventory maintenance cost within the planning cycle of automobile parts dealer $i$;

$b_{i}$ : Unit shortage cost of automobile parts dealer $i$;

$B_{i}$ : Total shortage costs within the planning cycle of automobile parts dealer $i$;

$k_{i}$ : The ordering time within the planning cycle of automobile spare parts dealer $i$ to the automobile parts manufacturing enterprise;

$G_{l i}$ : Fixed ordering cost of automobile parts dealer $i$;

$G_{2 i}$ : Variable ordering cost of automobile parts dealer $i$;

$D_{i}$ : Total cost of automobile spare parts dealer $i$ within the planning cycle to order goods from automobile parts manufacturing enterprise;

$R_{i}$ : Order batch of automobile parts dealer $i$ each time;

$X_{i}(t)$ : Random demand of customer of automobile spare parts dealer $i$;

$S_{i}$ : Selling profit of auto parts dealer $i$ within the planning cycle 。

To analyze and study the objective function and constraint condition of overall profits of multilevel inventory system, laying the theoretical foundation for further analysis of ordering strategy of each stock node.

\section{Multi-stage Inventory System Optimization and Simulation}

Use the logistics simulation software Extendsim development by USA company Imagine That, optimize and simulate multilevel inventory supply chain of $A$ company.

\subsection{Extendsim Model Construction}

Through the logistics simulation software Extendsim built overall structure of the automobile spare parts multilevel inventory simulation system, and establish the database, named the Inventory database in this paper, shown in Table 4:

Table 4. Data Table of Inventory Database

\begin{tabular}{ccc}
\hline Table name & Data Types & Data Description \\
\hline Input & Fixedly setting & $\begin{array}{c}\text { To save fixed and variable ordering coefficient, unit } \\
\text { inventory maintenance cost, unit shortage cost, unit } \\
\text { product profit }\end{array}$ \\
$\begin{array}{c}\text { All levels of } \\
\text { inventory node }\end{array}$ & $\begin{array}{c}\text { Fixedly setting, } \\
\text { dynamic } \\
\text { change }\end{array}$ & $\begin{array}{c}\text { To save reorder point of each inventory node, order } \\
\text { quantity, inventory level at present }\end{array}$ \\
$\begin{array}{c}\text { Each node cost } \\
\text { Demand of each } \\
\text { node }\end{array}$ & $\begin{array}{c}\text { Dynamic } \\
\text { change }\end{array}$ & $\begin{array}{c}\text { Dynamic } \\
\text { inventory maintenance cost, shortage cost, selling } \\
\text { profit }\end{array}$ \\
$\begin{array}{c}\text { change } \\
\text { associated }\end{array}$ & $\begin{array}{c}\text { Dynamic } \\
\text { change }\end{array}$ & $\begin{array}{c}\text { To save demand of each inventory node } \\
\text { To save total ordering cost, total inventory } \\
\text { maintenance cost, total shortage cost, total selling } \\
\text { profit }\end{array}$ \\
\hline
\end{tabular}

Overall structure of the Inventory database shown in Figure 1: 


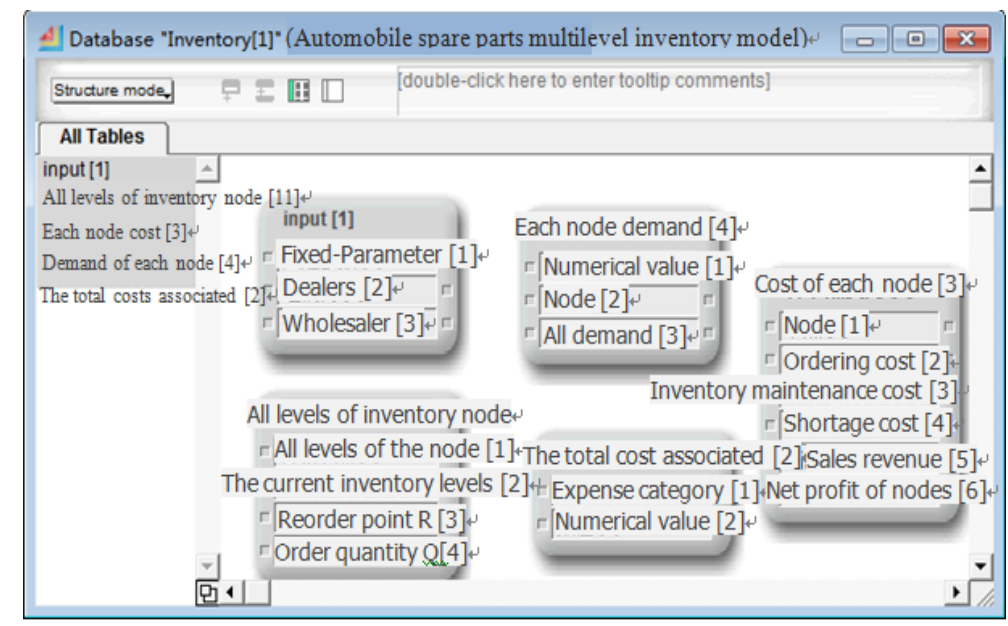

Figure 1. Inventory Database Structure

Then, save some fixed parameter values in the data table which associated with calculation of inventory cost, including fixed ordering cost, variable order cost, unit inventory maintenance cost, unit shortage cost, unit product profit and so on. For example: data table structure of each node cost shown in Figure 2.

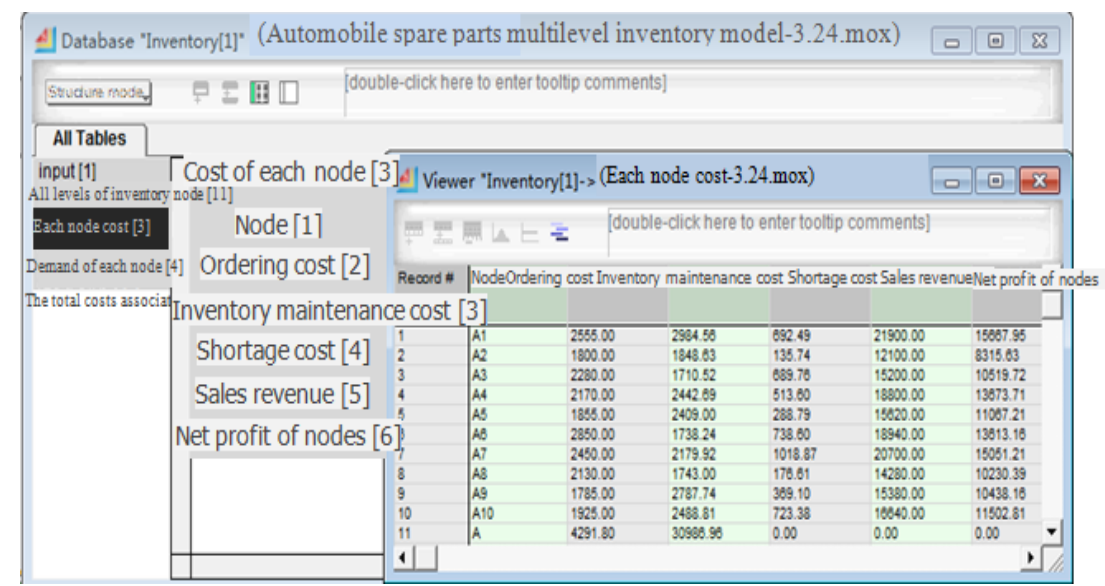

Figure 2. Data Table Structure of Each Node Cost

Automobile spare parts dealer inventory node inventory simulation model is composed by four parts, including demand processing section, check and order processing section, data processing section and data statistics section. Demand processing module generates the entity of customer demand in accordance with the time interval, then set the properties of demand on the entity, and then update inventory level in the inventory node at present according to demand. First, use the Create module generates entity of customer demand, then generates customer demand with Random Number module, and use the Set module to create DemandSize property of entity of customer demand and assigned demand to DemandSize property, then the demand made by Get modules. For example: customer demand processing module of automotive spare parts dealers shown in Figure 3. 


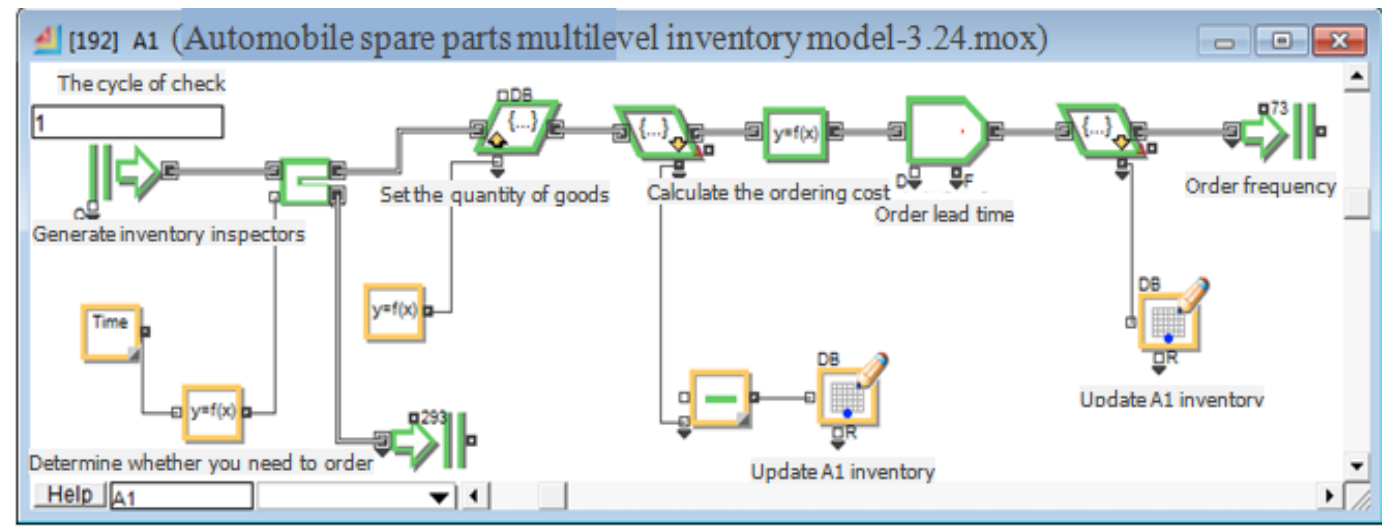

Figure 3. Customer Demand Processing Module of Automotive Spare Parts Dealers

Similarly, check library and order processing module of automobile spare parts dealer shown in Figure 4.

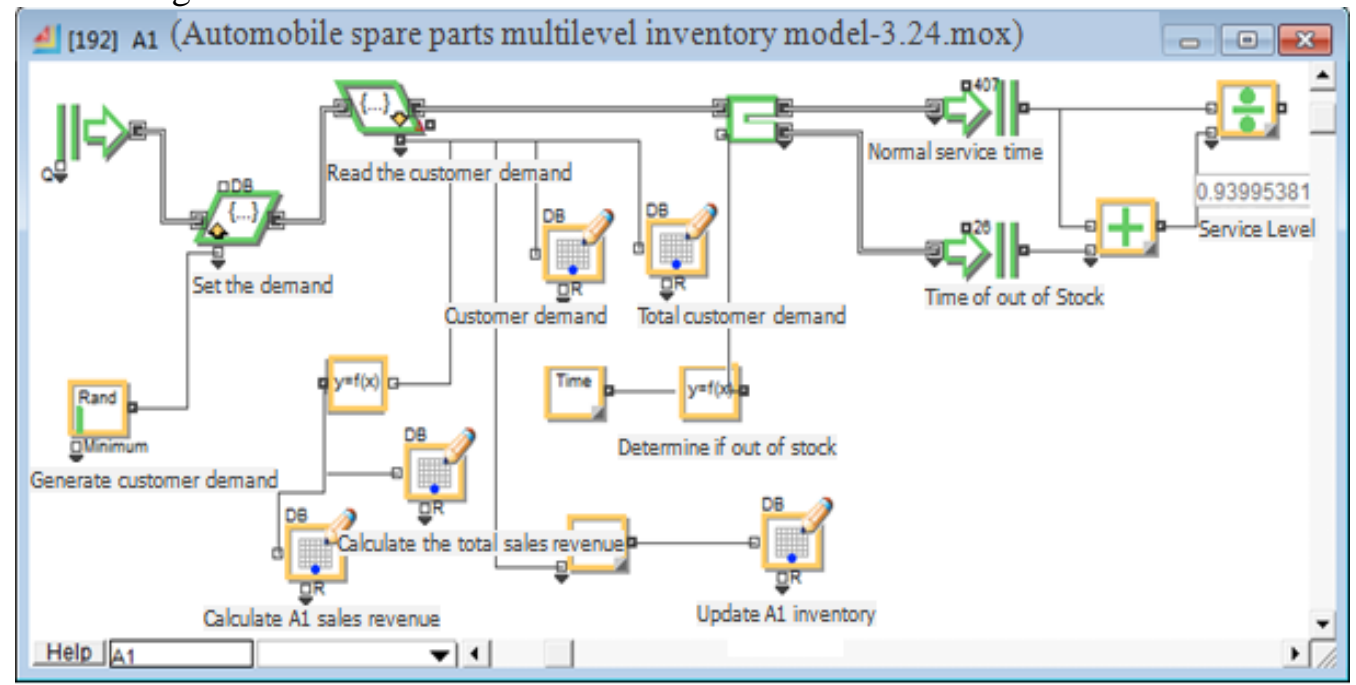
Figure 4. Check Library and Order Processing Module of Automobile Spare
Parts Dealer

The data processing section shown in Figure 5, due to the selling profit and ordering cost of dealer inventory nodes are calculated in demand processing module and check and order processing module separately, then written into the corresponding data table, the data processing section used to solve the inventory maintenance cost and shortage cost of inventory node in the simulation run cycle. 


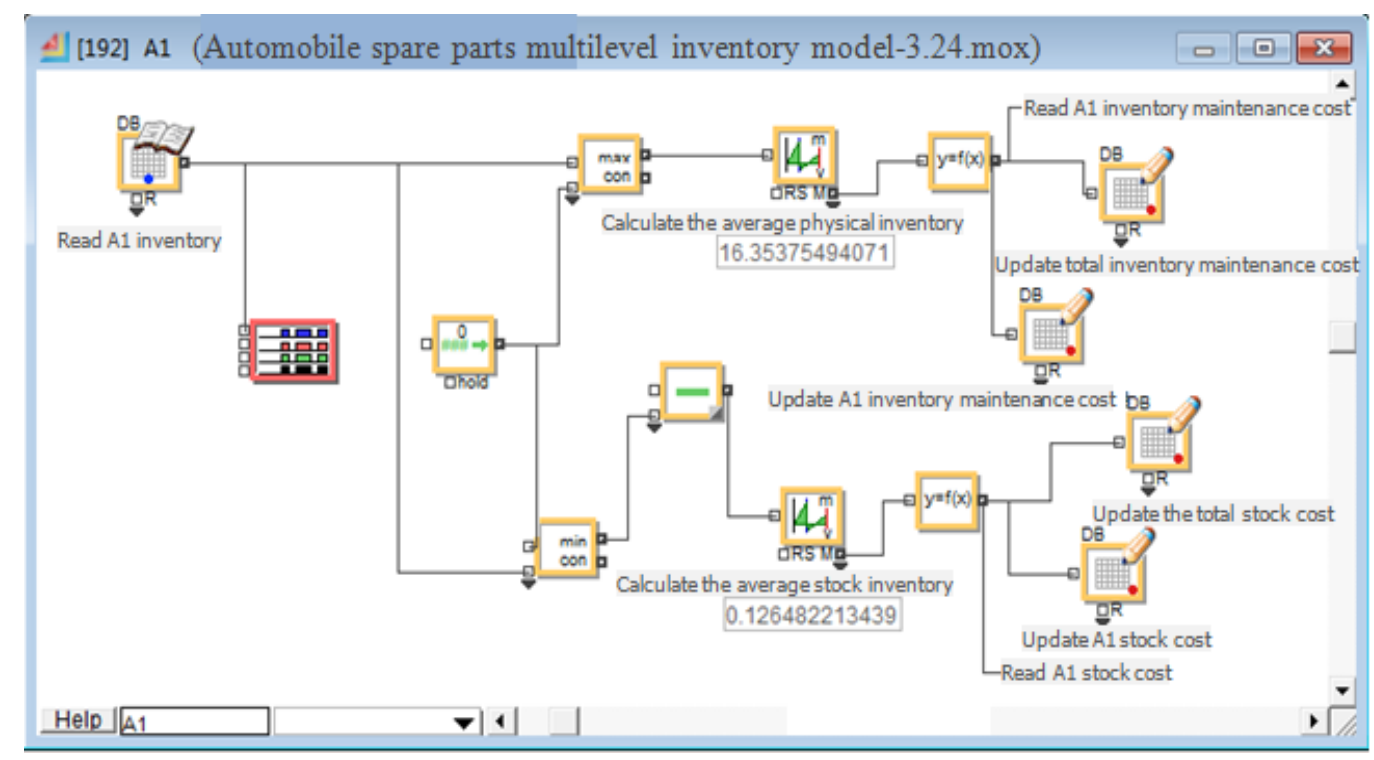

Figure 5. Data Processing Section of Automobile Spare Parts Dealer

Through modeling automobile spare parts multilevel inventory system, first describe the logical flow and overall structure and then build the overall database, built simulation module of automotive spare parts wholesaler and dealers respectively, including demand processing, check library and order processing, data processing and statistics section.

\subsection{Deterministic Input Parameters}

This paper set up the operation cycle of simulation system as 365 days a year. This paper studies multilevel inventory of a single spare parts, have a research on $A$ spare part which is sales of more selected in category of automobile spare parts wholesalers $A$, the purchase price of this spare parts from parts manufacturing enterprises is $120 \mathrm{RMB}$, the retail price of each automobile spare parts dealer is 140 $\mathrm{RMB}$, therefore selling profit of one spare parts in the whole supply chain is 20 RMB.

Automobile spare parts dealers and wholesaler use the way to check the library periodically, check the inventory regularly, every time order quantity is a fixed value, namely use (T, R, Q) ordering policy. The ordering policy of automobile spare parts dealers and wholesaler is $(1,5,10)$, namely check inventory every day, order 10 products from the automotive spare parts wholesaler when stocks below 5; the ordering policy of automobile spare parts wholesaler is $(15,550,550)$, namely ever 15 days, automotive spare parts wholesaler checks the inventory one time, order 550 products from the automotive components manufacturers when stocks below 550 .

The unit inventory maintenance cost of automobile spare parts dealers is 0.5 $\mathrm{RMB}$ per piece one day, the unit shortage cost is 9.5 RMB per piece one day; the unit inventory maintenance cost of automobile spare parts wholesaler is $0.2 \mathrm{RMB}$ per piece one day, the unit shortage cost is $3.8 \mathrm{RMB}$ per piece one day.

\subsection{Random Input Parameters}

Use the exponential distribution show customer demand time of each automobile spare parts dealer, uniform distribution every time demand. The order time, from automobile spare parts dealer orders from the automotive spare parts wholesalers to products arrive, and the order time, that automobile spare parts wholesaler orders from auto parts manufacturers, obey Poisson distribution. 
Table 5. The Random Input Parameters of Each Inventory Node

\begin{tabular}{cccc}
\hline Inventory node & $\begin{array}{c}\text { Mean of order lead } \\
\text { time (days) }\end{array}$ & $\begin{array}{c}\text { Mean of customer arrival } \\
\text { time interval (days) }\end{array}$ & $\begin{array}{c}\text { Customer } \\
\text { demand }\end{array}$ \\
\hline A1 & 0.4 & 0.9 & $1 \sim 4$ \\
A2 & 0.5 & 1.2 & $1 \sim 3$ \\
A3 & 0.6 & 1.2 & $1 \sim 4$ \\
A4 & 0.7 & 0.8 & $1 \sim 3$ \\
A5 & 0.7 & 0.9 & $1 \sim 3$ \\
A6 & 0.6 & 1 & $1 \sim 4$ \\
A7 & 0.7 & 0.9 & $1 \sim 4$ \\
A8 & 0.8 & 1 & $1 \sim 3$ \\
A9 & 0.8 & 1.2 & $1 \sim 4$ \\
A10 & 0.7 & 1 & $1 \sim 4$ \\
A & 8 & - & - \\
\hline
\end{tabular}

\section{The Simulation Results}

Set the corresponding parameter values of each module and Inventory database, then click the Run Simulation button to run the simulation. Because the influence of random input parameters, every result is not the same, So we need to do simulation experiment for many times to simulation model, so that count the output results, the simulation was ran 20 times. Theory inventory level changes of automobile spare parts wholesaler $A$ and dealer $A l$ in once simulation experiment of the simulation operation cycle are shown in Figure 6 and 7 separately:

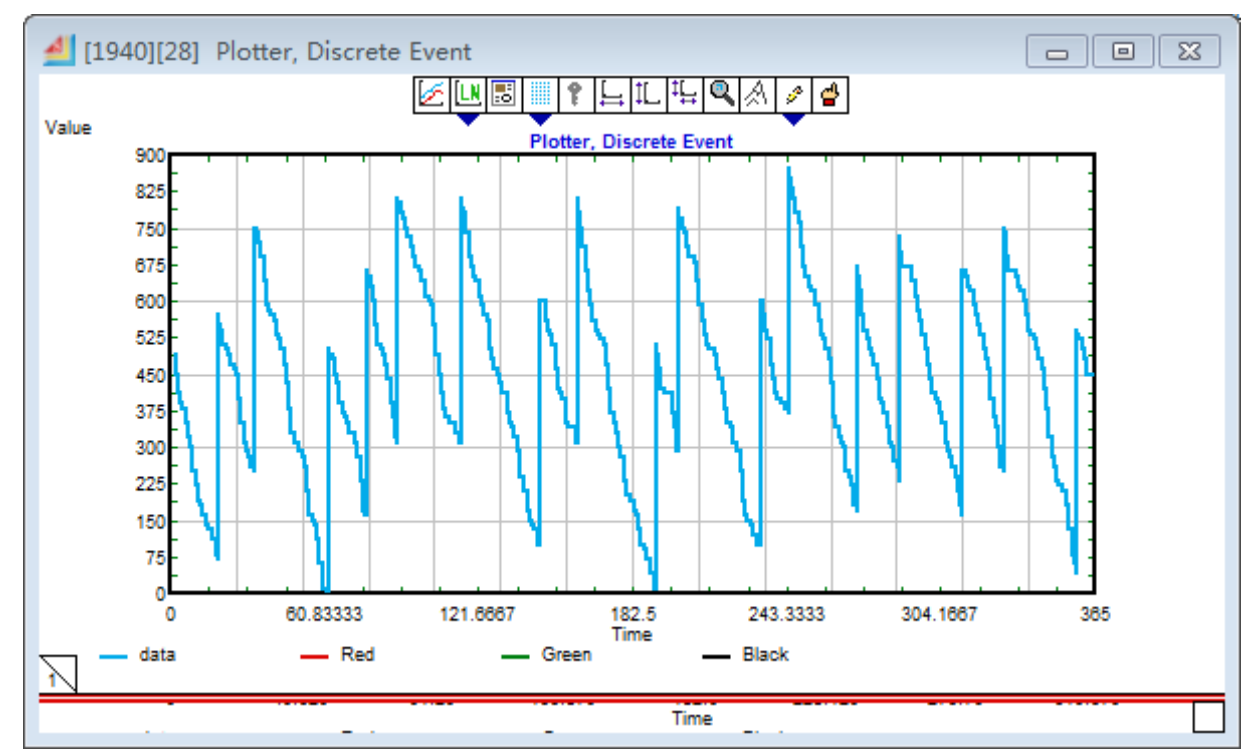

Figure 6. Theory Inventory Level of Automobile Spare Parts Wholesaler A 


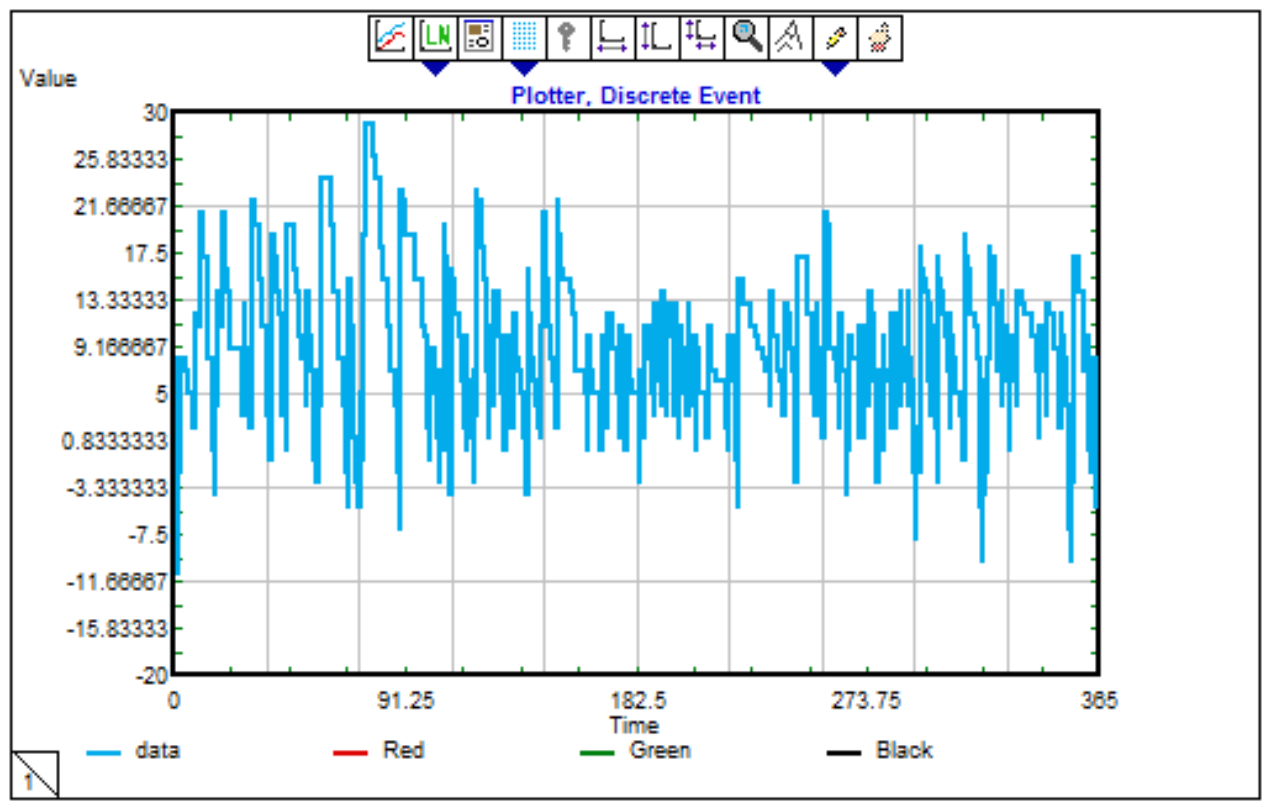

Figure 7. Theory Inventory Level of Automobile Spare Parts Dealers A1

Because there are a lot of random variables of automotive spare parts multistage inventory system which this article studies, including the inventory node customer demand, order lead time etc. The results of simulation optimization will be different. It is necessary to select several optimization results to compare and analyze. Obtained 10 simulation optimization results with the Optimizer module. Two of these simulation results shown in Figure 8 and Figure 9.

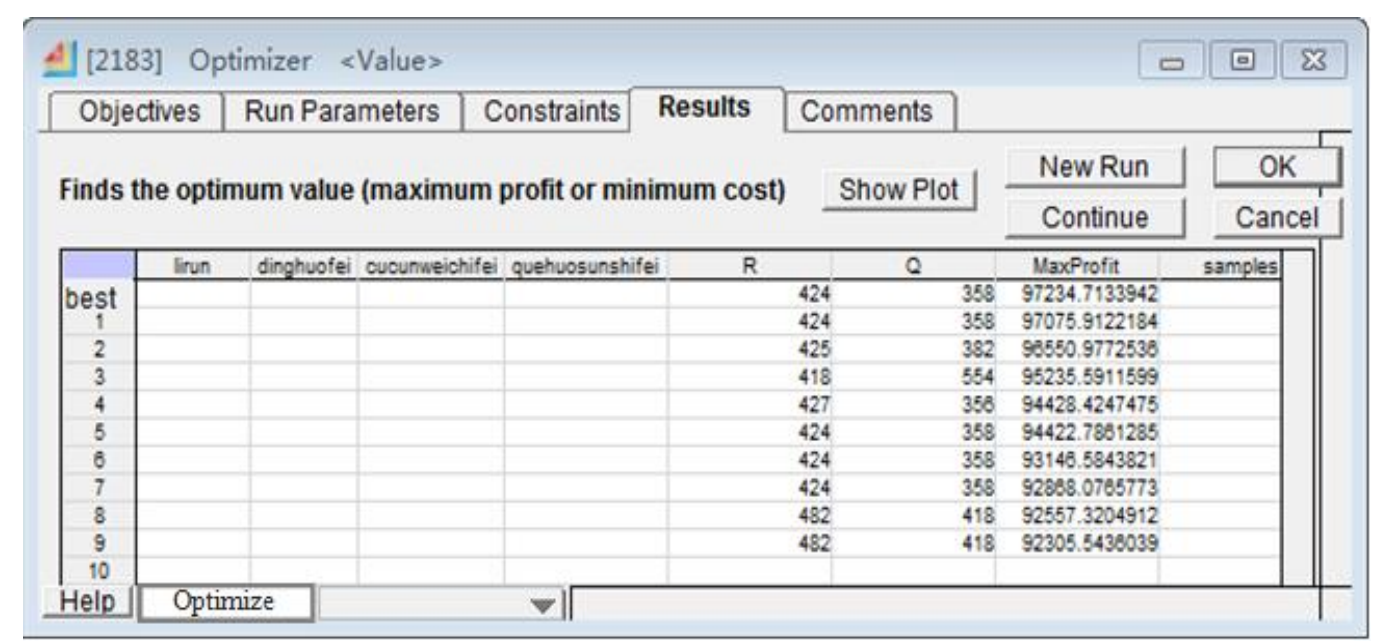

Figure 8.The Optimization Results 1 


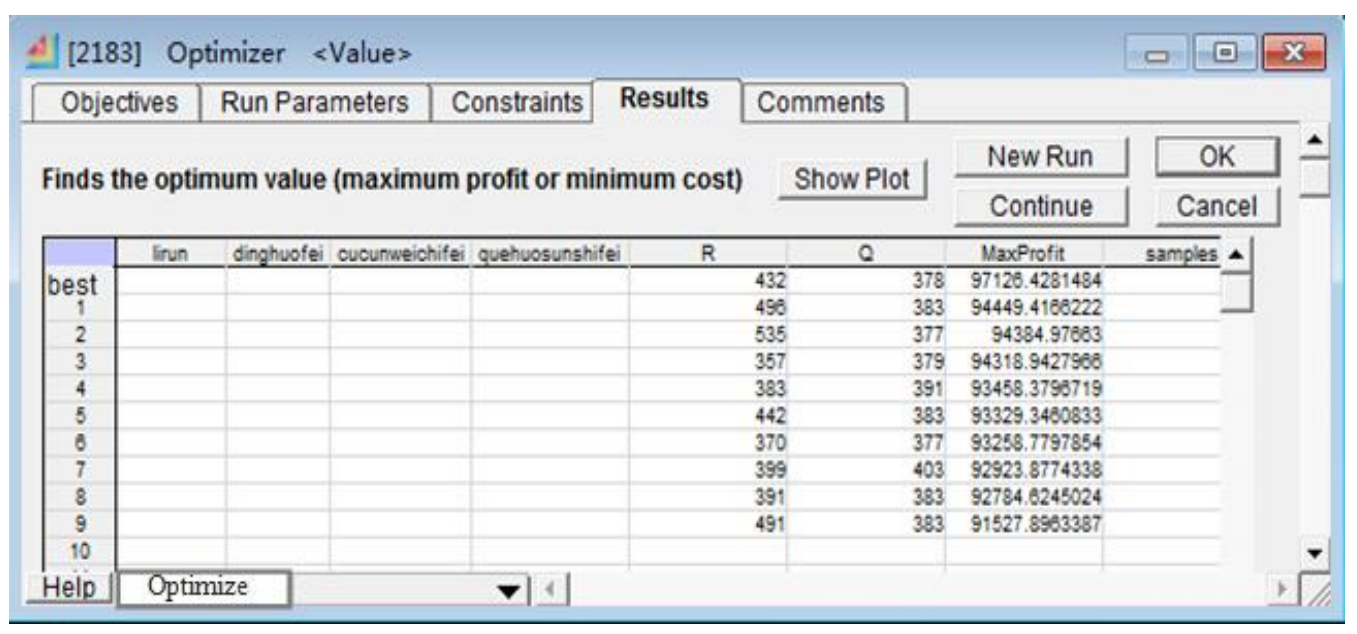

Figure 9.The Optimization Results 2

To extract the optimal result of each optimization results, as an input parameter to reenter multistage inventory simulation model running 20 times, get mean of each output results are normalized, written in the Table, as shown in Table 6:

Table 6. The Statistic Optimization Results

\begin{tabular}{ccccc}
\hline$(\mathrm{R}, \mathrm{Q})$ & $\begin{array}{c}\text { Total ordering } \\
\text { cost (RMB) }\end{array}$ & $\begin{array}{c}\text { Total inventory maintain } \\
\text { cost (RMB) }\end{array}$ & $\begin{array}{c}\text { Total shortage } \\
\text { coat(RMB) }\end{array}$ & $\begin{array}{c}\text { Net profit } \\
(\mathrm{RMB})\end{array}$ \\
\hline$(513,386)$ & 25949.2 & 51619.61 & 3396.495 & 88594 \\
$(486,382)$ & 25940.4 & 46992.79 & 9787.164 & 86839 \\
$(404,384)$ & 25944.8 & 40023.56 & 15467.12 & 88124 \\
$(395,393)$ & 25964.6 & 39505.01 & 13212.5 & 90877 \\
$(379,531)$ & 25049.6 & 45701.91 & 11830.6 & 86977 \\
$(476,401)$ & 25792.1 & 45185.09 & 8978.817 & 89603 \\
$(480,395)$ & 25969 & 44268.18 & 10634.33 & 88688 \\
$(432,416)$ & 25823.6 & 43858.65 & 11579 & 88298 \\
$(424,358)$ & 26259.2 & 40291.75 & 11869.45 & 91139 \\
$(432,378)$ & 26119.4 & 42861.4 & 10222.62 & 90356 \\
\hline
\end{tabular}

According to Table 6, the overall net profit of automotive spare parts multilevel inventory system under the original ordering policy is $81935.15 \mathrm{RMB}$, after simulation optimization we can get the inventory strategy, it increase overall net profit of automobile spare parts supply chain, and reduce the inventory cost.

\section{Conclusion}

This paper takes the automobile spare parts supply chain inventory to sales management as the starting point, systematically study the multilevel inventory management mode and its optimization method. Optimized inventory strategy make the total net profit of automobile spare parts of multilevel inventory system improved compared with the original ordering strategy multistage inventory system, the total net income has improved.

\section{References}

[1] M. K. Salameh and R. E. Ghattas, "Optimal just-in-time buffer inventory for regular preventive maintenance,” Int. J. Prod. Econ., vol. 74, no. 1, (2001), pp. 157-161. 
[2] R. J. Feng, "M Study on Spare Parts Inventory Management of A Company", Beijing Jiaotong University, (2009).

[3] H, S. Lau and A. H. L. Lau, "Supply Chain inventory management and the value of shared information", Management Science, vol. 46, no. 8, (2001).

[4] C. Zhang, "A review of the research of supply chain management in China," Journal of East China Jiaotong University, vol. 03, (2011), pp. 92-97.

[5] Y. Pang, Z. W. Wang and H. Wang, "Study on green supply chain management model in iron and steel manufacturing industry low carbon economy environment", Enterprise Economic, vol. 02, (2011), pp. 66-68.

[6] J. Chen and Y. B. Xiao, "New developments and research prospects in supply chain management", Journal of University of Shanghai for Science and Technology, vol. 06, (2011), pp. 694-700+508.

[7] S. H. Zhang, "Review and Outlook of Researches on Green Supply China Management", Logistics Technology, vol. Z1, (2010), pp. 177-181.

[8] F. Y. Chen, Y. Feng and D. Simchi-Levi, "Exaet evaluation of order fulfillment in multi-item or assembly postponement inventory systems with batch—ordering policies", National University of Singapore, (2005).

[9] R. Munson, "A stock rationing policy in a $(s, S)$ Controlled stochastic production system with 2-phase coxian processing times and lost sales", International Journal of Production Economics, vol. 46, no. 8, (2006).

[10] A. J. Clark and H. Scarf, "Optimal policies for a multi-echelon inventory problem", Management science, vol. 6, no. 4, (1960), pp. 475-490.

[11] X. L. Song, "Auto spare parts logistics and supply chain management," Logistics technology and Application, vol. 14, no. 2, (2009), pp. 88-90.

[12] J. S. Peng, "Customer Service Parts Management Systems in the Automobile Industry: Mining Value and Profit in the Spare Parts Supply Chain," Publishing House of Electronics Industry, (2007).

[13] C. T. Ding, "Logistics Management Mode of Spare Part for Automotive Aftermarket," Chongqing University, (2006).

[14] G. W. Dou and N. W. Xue, "Study on Demand Forecast of Automobile Spare-part for After Service," Logistics Technology, vol. 28, no, 10, (2005), pp. 4-7.

[15] X. Y. Zou and Y. Q. Xu, "The Comprehensive Application of ABC Methods to the 4S Automobile Spare Parts Stock the Management”, Logistics Technology, vol. 31, no. 9, (2008), pp. 30-33.

\section{Authors}

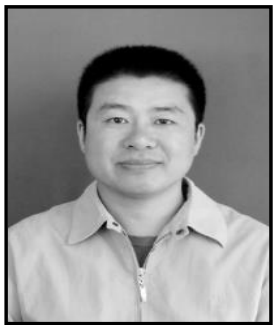

Hongxing Deng, received the Ph.D. degrees in physics, automobile application engineering, automobile application engineering respectively, from Northeast Forestry University, Harbin, China, in 2009.He is currently a Professor of Transportation College of Northeast Forestry University. His main research interests include automobile braking, logistics technology.

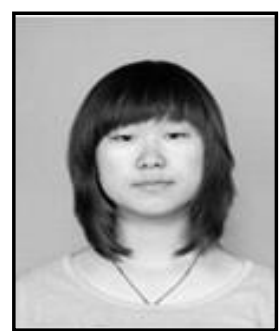

Ting Yuan, received the B.S degree in vehicle engineering from Northeast Forestry University, Harbin, China, in 2013.She is currently a graduate of Transportation College, Northeast Forestry University, Harbin, China.Her research focuses on logistics technology.

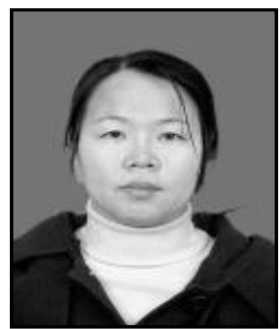

Chunli Yan, received the Ph.D. degrees in physics, automobile application engineering, automobile application engineering respectively, from Northeast Forestry University, Harbin, China, in 2010. She is currently an Associate Professor of Transportation College of Northeast Forestry University. Her research interests are focused on automobile theory. 